\title{
Pengembangan Media Pembelajaran Keterampilan Menyimak Teks Laporan Hasil Observasi dengan Articulate Storyline di SMAN 3 Bantul Tahun Ajaran 2021/2022
}

\author{
Anik Nurlatifah \\ (Corresponding Author) \\ Universitas PGRI Yogyakarta \\ Email: latifah.anik25@gmail.com \\ Primasari Wahyuni \\ Universitas PGRI Yogyakarta \\ Email: sariprima87@gmail.com \\ Fitri Jamilah \\ Universitas PGRI Yogyakarta \\ Email: fj7761@gmail.com
}

APA Citation: Nurlatifah, A., Wahyuni, P., \& Jamilah, F. (2021). Pengembangan Media Pembelajaran Keterampilan Menyimak Teks Laporan Hasil Observasi dengan Articulate Storyline di SMAN 3 Bantul Tahun Ajaran 2021/2022. Silampari Bisa: Jurnal Penelitian Pendidikan Bahasa Indonesia, Daerah, dan Asing, 4(2), 457-467. https://doi.org/10.31540/silamparibisa.v4i2.1491

\begin{abstract}
Abstrak
Media pembelajaran menyimak teks laporan hasil observasi yang selama ini digunakan masih bersifat audio visual yang bersumber dari Youtube. Hal ini membuat siswa kesulitan jika ingin mempelajari materi sebelumnya sehingga dibutuhkan media yang menarik dan bisa dipelajari secara berulang kali dengan digunakannya articulate storyline. Untuk itu, tujuan penelitian ini untuk mendeskripsikan hasil pengembangan media pembelajaran keterampilan menyimak teks laporan hasil observasi dengan articulate storyline di SMAN 3 Bantul, Tahun Ajaran 2021/2022. Metode penelitian yang digunakan adalah metode penelitian dan pengembangan dengan model pengembangan ADDIE. Penelitian dilakukan di SMAN 3 Bantul. Subjek yang digunakan siswa kelas $X$ IPS 2 berjumlah 15 siswa. Teknik pengumpulan data menggunakan observasi, angket, dan tes. Hasil dari penelitian menunjukkan: 1) penelitian ini menghasilkan produk media pembelajaran interaktif articulate storyline versi html5 dan aplikasi android bernama Media Belajar Bahasa Indonesia; 2) kualitas media pembelajaran interaktif articulate storyline, berdasarkan hasil penilaian dari ahli media sebesar 95\% dan ahli materi 92,5\%, sehingga dikategorikan sangat layak/valid; 3) ketertarikan siswa terhadap media pembelajaran articulate sroryline sebesar 94\% dikategorikan sangat baik; dan 4) keefektivan media articulate storyline setelah dilakukan ujicoba yaitu sebesar 81,64 N gain dan dikategorikan efektif.
\end{abstract}

Kata kunci: pengembangan, media pembelajaran, keterampilan menyimak, teks laporan hasil observasi, articulate storyline 


\title{
Development of Learning Media Skills for Listening to the Text of Observation Results Reports with Articulate Storylines at SMAN 3 Bantul Academic Year 2021/2022
}

\begin{abstract}
The learning media for listening to the text of the observation report that has been used so far is still audio-visual in nature, sourced from Youtube. This makes it difficult for students if they want to learn the previous material so that interesting media is needed and can be studied repeatedly by using articulate storylines. For this reason, the purpose of this study was to describe the results of developing learning media for listening skills to the text of the observation report with an articulate storyline at SMAN 3 Bantul, Academic Year 2021/2022. The research method used was a research and development method with the ADDIE development model. The research was conducted at SMAN 3 Bantul. The subjects used by class X IPS 2 students were 15 students. Data collection techniques using observation, questionnaires, and tests. The results of the study show: 1) this research produces an interactive learning media product, html5 version of articulate storyline and an android application called Indonesian Language Learning Media; 2) the quality of interactive learning media articulate storyline, based on the results of the assessment of media experts by $95 \%$ and material experts $92.5 \%$, so it is categorized as very feasible/valid; 3) student interest in articulate storyline learning media by $94 \%$ is categorized as very good; and 4) the effectiveness of the articulate storyline media after the trial was carried out, which was $81.64 \mathrm{~N}$ gain and categorized as effective.
\end{abstract}

Keywords: development, learning media, listening skills, observation report text, articulate storyline

\section{A. Pendahuluan}

Sistem pendidikan di Indonesia yang pada awalnya berupa tatap muka, berubah menjadi daring akibat pandemi. Selama pembelajaran daring siswa dituntut untuk belajar mandiri (Suardinata, 2021). Guru hanya sebagai fasilitator. Sering kali siswa merasa jenuh saat pembelajaran daring berlangsung. Masalah ini harus diperhatikan oleh guru terutama dalam menciptakan pembelajaran yang menyenangkan dan interaktif. Salah satu cara untuk menciptakan pengalaman belajar yang interaktif dan menyenangkan adalah dengan menyajikan dan mengemas media pembelajaran dengan baik (Ulfah, 2017).

Media pembelajaran adalah sarana untuk memberikan dan menyampaikan materi pembelajaran oleh guru kepada peserta didik. Martin dan Briggs (1986), dalam Wena (2009), mengatakan bahwa media merupakan segala sesuatu yang dapat digunakan untuk proses berkomunikasi dengan siswa. Media pembelajaran yang menarik, kreatif, dan inovatif sangat berguna dalam penyampaian materi pelajaran. Pemilihan media pembelajaran sangat diperlukan guna menunjang pencapaian indikator kompetensi (Trisnawati, dkk. 2020). Terdapat berbagai macam jenis media pembelajaran, diantaranya yaitu media pembelajaran interaktif. Media jenis ini menuntut keterlibatan siswa. Hal ini tentunya akan membuat siswa terpacu untuk aktif selama pembelajaran daring. Menurut Hofstetter, dalam Shalikhah (2017) menjelaskan bahwa multimedia interaktif merupakan kegiatan 
memanfaatkan komputer untuk proses penggabungan teks, grafik, audio, gambar atau animasi, dan video menjadi satu kesatuan melalui tautan dan tool yang sesuai dan memungkinkan pengguna melakukan navigasi, interaksi, kreasi, dan komunikasi. Media interaktif ini juga dibutuhkan dalam mengaktifkan siswa dalam pembelajaran menyimak teks laporan hasil observasi.

Teks laporan hasil observasi merupakan salah satu materi pelajaran Bahasa Indonesia kelas X SMA/SMK di semester 1. Teks laporan hasil observasi adalah teks yang berisi hasil pengamatan yang telah dilakukan (Ambarawati, 2020). Laporan hasil observasi dapat berbentuk lisan maupun tulisan. Hal ini disebutkan Suherli, dkk. (2017) yang menyatakan bahwa sebuah teks laporan hasil observasi dapat disajikan dalam bentuk teks tertulis maupun lisan.

Berdasarkan hasil pengamatan peneliti selama melaksanakan kegiatan Praktek Pengalaman Lapangan (PPL) di SMA N 3 Bantul, keterampilan menyimak siswa pada Mata Pelajaran Bahasa Indonesia dikategorikan cukup baik. Namun, siswa cenderung lebih menyukai penjelasan materi menggunakan media audio visual untuk memperhatikan materi. Guru menggunakan media animasi untuk pembelajaran, sehingga siswa harus mengunduh materi berupa video yang diberikan. Pemberian materi berupa video tentunya menggunakan ruang penyimpanan perangkat yang cukup besar. Siswa akan menghapus sebagian materi pembelajaran terdahulu, sehingga akan kehilangan materi pelajaran terdahulu. Hal tersebut tentunya membuat siswa kesulitan jika ingin mempelajari materi terdahulu. Untuk itu, untuk mengatasi permasalahan ini salah satu caranya dengan menggunakan media articulate storyline.

Articulate storyline merupakan aplikasi pembuat media pembelajaran interaktif dan produk yang dihasilkan dapat diakses melalui link yang diberikan. Apabila siswa ingin mengulang materi dapat mengakses pembelajaran melalui web tersebut. Menurut Yumini \& Rakhmawati (2015), media pembelajaran yang menggunakan articulate storyline memiliki berbagai unsur yang meliputi: teks, audio, gambar, animasi, dan tes evaluasi. Menurut Sapitri \& Bentri (2020), hasil akhir articulate storyline berbasis web (html5) dan dapat dijalankan di laptop, tablet dan smartphone. Hal ini tentunya akan memudahkan siswa dalam mengakses media untuk kegiatan pembelajaran khususnya dalam penelitian ini pada pembelajaran menyimak.

Menyimak merupakan kegiatan mendengarkan dan memahami bunyi bahasa. Menurut Tarigan dalam Nurhayati (2010) menyimak dapat digolongkan menjadi dua, antara lain: menyimak ekstensif dan menyimak intensif. Berdasarkan hasil pengamatan peneliti siswa kurang menyimak materi yang diberikan karena pembelajaran bersifat satu arah dan tidak melibatkan interaksi siswa. Hal ini menyebabkan siswa menjadi jenuh. Diharapkan dengan menggunakan articulate storyline pembelajaran menjadi lebih interaktif, sehingga membuat siswa tidak jenuh.

Penelitian yang relevan pernah dilakukan oleh Nugraheni (2018) tentang pengembangan media pembelajaran interaktif dengan menggunakan articulate storyline pada Mata Pelajaran Sejarah Indonesia Kelas X di SMK Negeri 1 Kebumen. Hasil penelitian menunjukkan bahwa media articulate storyline layak digunakan sebagai media pembelajaran Sejarah Indonesia. Hal ini dibuktikan dengan skor rata-rata validasi ahli materi sebesar $72,3 \%$. Skor rata-rata validasi ahli media sebesar $78,54 \%$. Peningkatan minat belajar siswa menggunakan uji_N 
gain yaitu sebesar 0,71 dan pendapat guru yang memperoleh uji_N gain sebesar 0,8 .

Penelitian yang relevan lainnya dilakukan oleh Prathamie (2016) tentang pengembangan media pembelajaran keterampilan menyimak pada materi L'identité melalui Adobe Flash CS6 dengan berbasis mobile apllication bersistem operasi android pada siswa Kelas $X$. Hasil penelitian menunjukkan bahwa media pembelajaran menggunakan Adobe Flash CS6 layak digunakan sebagai media pembelajaran keterampilan menyimak pada materi L'identité untuk siswa kelas $X$. penilain oleh guru sebesar $87 \%$ dan penilaian oleh siswa sebesar $82,5 \%$. Kedua penilaian tersebut dikategorikan sangat baik.

Berdasarkan latar belakang permasalahan yang telah diuraikan, rumusan masalah sebagai berikut: 1) Bagaimanakah cara mengembangkan media pembelajaran keterampilan menyimak teks laporan hasil observasi dengan articulate storyline di SMA N 3 Bantul tahun 2021/2022?; 2) Bagaimanakah kualitas media pembelajaran keterampilan menyimak dengan articulate storyline?; 3) Bagaimanakah daya tarik siswa terhadap media pembelajaran keterampilan menyimak dengan articulate storyline yang dikembangkan?; dan 4) Bagaimanakah keefektivan media articulate storyline dalam pembelajaran keterampilan menyimak teks laporan hasil observasi di SMA N 3 Bantul tahun 2021/2022?. Dari hasil penelitian ini diharapkan media pembelajaran keterampilan menyimak teks laporan hasil observasi dengan articulate storyline yang dikembangkan dapat dijadikan solusi bagi guru bahasa Indonesia dalam meningkatkan kemampuan siswa dalam menyimak teks laporan hasil observasi.

\section{B. Metode Penelitian}

Penelitian ini menggunakan metode penelitian pengembangan (research and development). Metode penelitian ini bertujuan menghasilkan produk tertentu. Penelitian ini menggunakan model penelitian pengembangan ADDIE. Langkahlangkah model penelitian pengembangan ADDIE seperti yang dijelaskan Agustien, dkk. (2018) memiliki 5 tahapan, yaitu: analyze (menganalisis), design (merancang), development (mengembangkan), implementation (mengimplementasikan), dan evaluation (mengevaluasi).

Penelitian dilakukan penulis di SMAN 3 Bantul pada bulan September tahun ajaran 2021/2022. Desain uji coba produk pada penelitian ini menggunakan PreExperimental Design One-Group Pretest-Posttest Design. Pemilihan desain ini dikarenakan tidak adanya kelas kontrol. Sampel sebelum mendapat perlakuan diberi pre test terlebih dahulu. Hal ini dilakukan untuk mendapatkan data yang lebih akurat. Adapun gambaran desain sebagai berikut.

$$
\mathrm{O}_{1} \times \mathrm{O}_{2}
$$

Keterangan: $\mathrm{O}_{1}=$ Nilai Pre Test (sebelum diberi perlakuan)

$\mathrm{O}_{2}=$ Nilai Post Test (setelah diberi perlakuan) 
Anik Nurlatifah, Primasari Wahyuni, Fitri Jamilah

Pengembangan Media Pembelajaran Keterampilan Menyimak Teks Laporan Hasil Observasi dengan Articulate Storyline di SMAN 3 Bantul Tahun Ajaran 2021/2022

Sampel yang diambil pada penelitin ini yaitu siswa kelas X IPS 2 yang berjumlah 15 siswa. Teknik pengumpulan data yang dilakukan yaitu observasi, angket, dan tes. Angket yang digunakan dalam penelitian ini meliputi: angket ahli media, angket ahli materi, angket respons siswa, dan angket respons guru. Angket ahli media menggunakan skala likert dengan kriteria sangat baik, baik, cukup, dan kurang. Angket ahli materi dan respon guru menggunakan skala likert dengan kriteria sangat setuju, setuju, kurang setuju, dan tidak setuju. Angket respons siswa menggunakan skala Guttman dalam penilaiannya, yaitu: ya dan tidak (Sugiyono, 2019). Pemilihan skala ini untuk memudahkan siswa dalam pengisian angket. Tes yang dilakukan di kelas memiliki dua fungsi yaitu mengukur siswa dan keefektifan media yang digunakan dalam pembelajaran menyimak.

Analisis keefektifan media pada keterampilan menyimak peserta didik menggunakan uji-N gain. Sebelum dilakukan uji-N gain dilakukan uji normalitas dan uji beda. Apabila terdapat perbedaan yang signifikan antara sebelum dan sesudah sampel diberi perlakuan, dilakukan perhitungan skor $\mathrm{N}$ gain. Adapun rumus uji $\mathrm{N}$ gain menurut Hake dalam Rosita, dkk. (2017) sebagai berikut.

$$
\mathrm{N}-\text { gain }(\mathrm{g})=\frac{\text { Nilai Post Test }- \text { Nilai Pre Test }}{\text { Nilai Maksimum }- \text { Nilai Pre Test }}
$$

Tabel 1. Kategori Tafsiran Efektivitas N-Gain

\begin{tabular}{cc}
\hline Presentase (\%) & Tafsiran \\
\hline$<40$ & Tidak Efektif \\
\hline $40-55$ & Kurang Efektif \\
\hline $56-75$ & Cukup Efektif \\
\hline$<76$ & Efektif
\end{tabular}

\section{Hasil Penelitian dan Pembahasan}

\section{Hasil Penelitian}

Media yang digunakan pada penelitian ini adalah articulate storyline. Penelitian ini dilaksanakan di SMAN 3 Bantul. Media dikembangkan melalui beberapa tahap yang harus dilalui sebelum menjadi media pembelajaran interaktif. Peneliti menggunakan model pengembangan ADDIE. Berikut tahapan-tahapan yang harus dilalui meliputi: tahap analysis, design, development, implementation, dan evaluation.

a. Tahap Analysis

Berdasarkan observasi yang dilakukan oleh peneliti pada saat PPL (Praktik Pengalaman Lapangan), bahwa di SMAN 3 Bantul siswa masih kesulitan dalam menyimak materi pelajaran. Kemudian, melakukan analisis Kompetensi Dasar (KD) yang ingin dicapai. Penelitian dilakukan pada tahun ajaran baru 2021/2022 sehingga fokus penelitian mengacu teks laporan hasil observasi. Setelah menganalisis KD, langkah selanjutnya yaitu menganalisis kebutuhan media.

b. Tahap Design

Pembuatan desain awal membutuhkan beberapa hal yaitu pembuatan naskah media dan alur media. Pembuatan naskah media membutuhkan materi pelajaran untuk dimasukkan ke dalam media dan diolah untuk mencapai tujuan pembelajaran. Materi yang digunakan pada penelitian ini adalah teks laporan hasil 
Anik Nurlatifah, Primasari Wahyuni, Fitri Jamilah

Pengembangan Media Pembelajaran Keterampilan Menyimak Teks Laporan Hasil Observasi dengan Articulate Storyline di SMAN 3 Bantul Tahun Ajaran 2021/2022

observasi untuk kelas X SMA. Alur media terdiri dari halaman login dan beranda. Beranda berisi menu kompetensi dasar (KD), materi, video pengamatan, kuis, pengembang, dan referensi.

c. Tahap Development

Terdapat dua langkah-langkah pada tahap ini yaitu pembuatan media dan validasi media. Skor yang diperoleh dari ahli media adalah 57 dari skor maksimal 60 . Jadi persentase yang diperoleh sebesar 95\% dan dapat dikategorikan sangat layak. Skor yang diperoleh dari ahli materi diperoleh skor 37 dari skor maksimal 40. Persentase variabel yang diperoleh sebesar 92,5\% sehingga media dapat digunakan sebagai media pembelajaran.

d. Tahap Implementation

Setelah media pembelajaran divalidasi oleh ahli media dan materi, peneliti melakukan penelitian di SMAN 3 Bantul. Sebelum dilakukan pengujian media peneliti terlebih dahulu meminta validasi Rencana Pelaksanaan Pembelajaran (RPP) dan silabus oleh guru pengampu Mata Pelajaran Bahasa Indonesia kelas X IPS 2. Setelah itu, dilakukan pengujian media dan penyebaran angket. Persentase yang diperoleh dari hasil angket siswa sebesar $94 \%$ dan termasuk dalam kategori sangat baik. Oleh karena itu, dapat disimpulkan bahwa ketertarikan siswa terhadap media pembelajaran interaktif menggunakan articulate storyline sangat tinggi. Berdasarkan data respons guru diperoleh skor 36 dari skor maksimal 40. Persentase yang diperoleh sebesar $90 \%$. Hal ini menujukkan respons guru terhadap media articulate storyline sangat baik.

e. Tahap Evaluation

Nilai pre test dan post test diperoleh data rata-rata nilai pre test dari sampel yang berjumlah 15 yaitu 80 . Nilai rata-rata post test dari sampel yang sama yaitu 95. Uji beda dianalisis menggunakan nonparametrik Wilcoxon dengan hasil sebagai berikut.

\section{Test Statistics ${ }^{a}$}

\begin{tabular}{lr} 
& \multicolumn{2}{c}{$\begin{array}{c}\text { Nilai Posttest - } \\
\text { Nilai Pretest }\end{array}$} \\
\hline$Z$ & $-3.415^{\mathrm{b}}$ \\
\hline Asymp. Sig. (2-tailed) & .001 \\
\hline a. Wilcoxon Signed Ranks Test & \\
b. Based on negative ranks. &
\end{tabular}

Berdasarkan data di atas diketahui bahwa nilai sig. sebesar 0.001 . Nilai ini $<$ 0.025 maka Ho yang menyatakan tidak ada perbedaan rata-rata di antara kedua data (pre test dan post test) ditolak. Oleh karena itu,dapat disimpulkan bahwa perbedaan antara hasil pre test dan post test siswa signifikan.

Setelah data diketahui ada perbedaan yang signifikan, langkah selanjutnya yaitu dilakukan uji keefektivan menggunakan uji-N Gain. Analisis skor N Gain menggunakan bantuan SPSS 24. Selanjutnya, untuk menentukan kategori tafsiran efektivitas Uji-N Gain, skor N Gain yang diperoleh dikali 100. 


\begin{tabular}{|c|c|c|c|c|c|}
\hline \multicolumn{6}{|c|}{ Descriptives } \\
\hline & \multicolumn{3}{|c|}{ Kelas Sampel } & Statistic & Error \\
\hline $\mathrm{N}$ Gain & 1 & Mean & & 81.64 & 6.823 \\
\hline \multirow[t]{12}{*}{ Prosen } & & 95\% Confidence Interval for & Lower Bound & 67.01 & \\
\hline & & Mean & Upper Bound & 96.28 & \\
\hline & & $5 \%$ Trimmed Mean & & 83.17 & \\
\hline & & Median & & 100.00 & \\
\hline & & Variance & & 698.282 & \\
\hline & & Std. Deviation & & 26.425 & \\
\hline & & Minimum & & 36 & \\
\hline & & Maximum & & 100 & \\
\hline & & Range & & 64 & \\
\hline & & Interquartile Range & & 43 & \\
\hline & & Skewness & & -1.056 & .580 \\
\hline & & Kurtosis & & -.629 & 1.121 \\
\hline
\end{tabular}

Berdasarkan data di atas mean yang diperoleh dari N Gain Prosen sebesar 81,64 . Nilai $81,64>76$, maka media dikatakan efektif pada keterampilan menyimak teks laporan hasil observasi. Hal ini menunjukkan bahwa media pembelajaran interaktif menggunakan articulate storyline efektif digunakan sebagai media pembelajaran pada keterampilan menyimak teks laporan hasil observasi kelas $X$ SMA.

\section{Pembahasan}

Pengembangan media pembelajaran keterampilan menyimak teks laporan hasil observasi dengan articulate storyline di SMAN 3 Bantul Tahun Ajaran 2021/2022 layak dan efektif digunakan oleh siswa. Selain itu, kelebihan media aplikasi articulate storyline yang dikembangkan pada media pembelajaran keterampilan menyimak teks laporan hasil observasi adalah dapat diakses secara luring. Hal ini menunjukkan bahwa aplikasi articulate storyline tidak hanya layak dan efektif digunakan pada Mata Pelajaran Bahasa Indonesia yaitu khususnya pada materi menyimak teks laporan hasil observasi, tetapi juga layak dan efektif digunakan pada Mata Pelajaran Ekonomi (Sapitri \& Bentri, 2020) dan Mata Pelajaran Sejarah Indonesia (Nugraheni, 2018).

Pengembangan media pembelajaran keterampilan menyimak dengan articulate storyline menggunakan model pengembangan ADDIE. Tahap pengembangan yang pertama yaitu analisis (analysis). Pada tahap analisis peneliti melakukan analisis permasalahan di SMAN 3 Bantul, analisis KD, dan analisis kebutuhan media. Berdasarkan hasil dari observasi ditemukan permasalahan bahwa di SMAN 3 Bantul yaitu keterampilan menyimak siswa kelas $X$ cukup baik sehingga masih perlu ditingkatkan. Selain itu, siswa kurang menyimak materi pembelajaran yang diberikan secara satu arah. Pada tahun ajaran 2021/2022 ini pembelajaran masih dilakukan secara daring.

Pembelajaran daring yang tidak melibatkan keaktifan, menyebabkan siswa menjadi jenuh dalam belajar. Setelah mendapatkan permasalahan langkah selanjutnya menganalisis KD. Dikarenakan penelitian ini dilakukan di semester ganjil sehingga KD yang dipilih yaitu 3.1 yang berisi materi teks laporan hasil observasi. Selanjutnya, dilakukan analisis kebutuhan media. Bahan dan alat yang 
dibutuhkan dalam pengembangan media pembelajaran interaktif articulate storyline meliputi: materi pelajaran; media articulate storyline; aplikasi anymaker , untuk membuat video; website 2 apk builder pro, untuk mengubah html 5 menjadi aplikasi android; audio, untuk mengisi suara di media pembelajaran interaktif articulate storyline; dan aset-aset pembangun media seperti: gambar, simbol, dan ikon. Asetaset ini digunakan untuk melengkapi kebutuhan media yang akan dibuat.

Tahap pengembangan kedua yaitu perancangan (design). Pada tahap ini peneliti melakukan perancangan media. Hal yang dibutuhkan dalam proses perancangan media antara lain naskah dan alur media. Materi pelajaran yang digunakan pada penelitian ini adalah teks laporan hasil observasi, yang akan digunakan sebagai bahan pembuatan naskah. Teks laporan hasil observasi merupakan materi kelas $X$ semester ganjil. Alur media digunakan sebagai pedoman awal dalam pembuatan media pembelajaran interaktif.

Tahap pengembangan ketiga yaitu development. Pada tahap ini peneliti melakukan pengembangan media. Terdapat dua tahapan dalam tahap ini, yaitu pembuatan media dan validasi media. Media dikembangkan sesuai dengan alur yang sudah dibuat. Setelah pembuatan media selesai dilakukan validasi media oleh validator. Terdapat dua validasi yang dilakukan, yaitu validasi media dan materi. Berdasarkan hasil validasi dari ahli media diperoleh persentase sebesar 95\% dan dapat dikategorikan sangat layak. Hasil validasi dari ahli materi diperoleh persentase sebesar 92,5\% dan dikategorikan sangat layak. Berdasarkan penilaian dari ahli media dan materi dapat disimpulkan bahwa media pembelajaran keterampilan menyimak dengan articulate storyline sangat layak digunakan sebagai media pembelajaran.

Hasil akhir dari pengembangan media ini berupa web html 5 dan aplikasi android yang diberi nama Media Belajar Bahasa Indonesia, untuk pengguna smartphone android. Sebelum menggunakan Aplikasi Media Belajar Bahasa Indonesia, siswa terlebih dahulu mengunduh aplikasi melalui link yang diberikan peneliti. Kelebihan aplikasi Media Belajar Bahasa Indonesia adalah dapat diakses saat offline. Kekurangan dari aplikasi tersebut adalah siswa harus mengunduh dahulu sebelum menggunakannya. Kapasitas aplikasi hanya $11 \mathrm{Mb}$, sehingga saat siswa menginstal aplikasi tidak memerlukan ruang penyimpanan yang banyak.

Tahap pengembangan keempat yaitu implementation. Setelah media dikatakan sangat layak oleh ahli, langkah selanjutnya dilakukan pengujian media kepada peserta didik. Hal ini dilakukan untuk mengetahui keefektivan media pada peningkatan keterampilan menyimak teks laporan hasil observasi. Sampel yang digunakan untuk uji coba media pembelajaran interaktif articulate storyline adalah siswa kelas X IPS 2 yang berjumlah 15 siswa. Dikarenakan masih dalam kondisi covid sehingga kegiatan penelitian hanya dapat dilakukan dengan jumlah tersebut. Sebelum dilakukan pengujian media terlebih siswa diberikan pre test sebagai tolak ukur kemampuan keterampilan menyimak. Selanjutnya, siswa diberikan post test setelah menggunakan media pembelajaran articulate storyline. Angket untuk siswa dan guru diberikan setelah pengujian media. Angket digunakan untuk mengetahui ketertarikan siswa terhadap media pembelajaran articulate storyline. Berdasarkan hasil angket, persentase yang diperoleh sebesar $94 \%$ dan termasuk dalam kategori sangat baik. Hal ini menunjukkan ketertarikan siswa terhadap media pembelajaran 
Anik Nurlatifah, Primasari Wahyuni, Fitri Jamilah

Pengembangan Media Pembelajaran Keterampilan Menyimak Teks Laporan Hasil Observasi dengan Articulate Storyline di SMAN 3 Bantul Tahun Ajaran 2021/2022

keterampilan menyimak teks laporan hasil observasi dengan articulate storyline sangat tinggi.

Tahap pengembangan kelima yaitu evaluation. Setelah mendapatkan hasil dari implementasi kemudian data dianalisis. Pertama, hasil dari nilai pre test dan post test peserta didik dilakukan penilaian dan diberi skor. Kedua, dilakukan analisis uji normalitas menggunakan bantuan SPSS 24. Berdasarkan hasil analisis data diketahui nilai signifikan menurut perhitungan Shapiro-Wilk sebesar 0,031. Nilai 0,031<0,05 maka nilai pre test dan post test dikatakan tidak berdistribusi normal. Selanjutnya, dilakukan analisis uji beda menggunakan nonparametrik Wilcoxon dan diperoleh nilai sig. sebesar 0.001 . Nilai ini $<0.025$ maka Ho yang menyatakan tidak ada perbedaan rata-rata di antara kedua data (pre test dan post test) ditolak. Oleh karena itu, dapat disimpulkan bahwa perbedaan antara hasil pre test dan post test siswa signifikan. Ketiga, untuk mengetahui keefektifan media pembelajaran interaktif articulate storyline, dilakukan analisis Uji-N Gain. Kategori keefektivan menggunakan kriteria dari Hake, sehingga skor N Gain diubah ke persen dengan cara skor $\mathrm{N}$ gain dikali 100. Berdasarkan tabel hasil uji-N Gain diketahui mean dari N Gain Prosen sebesar 81,64. Nilai 81,64 > 76 dan termasuk dalam kategori efektif. Hal ini menunjukkan bahwa media pembelajaran keterampilan menyimak dengan articulate storyline efektif digunakan sebagai media pembelajaran keterampilan menyimak teks laporan hasil observasi di SMA N 3 Bantul tahun 2021/2022.

\section{Simpulan dan Saran}

Pengembangan media pembelajaran keterampilan menyimak teks laporan hasil observasi dengan articulate storyline di SMAN 3 Bantul Tahun Ajaran 2021/2022 layak dan efektif digunakan oleh siswa. Kelebihan media aplikasi articulate storyline yang dikembangkan pada media pembelajaran keterampilan menyimak teks laporan hasil observasi adalah dapat diakses secara luring. Selain itu, kapasitas aplikasi hanya $11 \mathrm{MB}$, sehingga saat siswa menginstal aplikasi tidak memerlukan ruang penyimpanan yang banyak. Kekurangan dari media yang dikembangkan yaitu siswa harus mengunduh dahulu sebelum menggunakannya.

Pengembangan media pembelajaran keterampilan menyimak dengan articulate storyline ini dikembangkan menggunakan model pengembangan ADDIE. Berdasarkan hasil validasi dari validator media diperoleh hasil bahwa media pembelajaran interaktif menggunakan articulate storyline sangat layak/valid digunakan sebagai media pembelajaran interaktif. Persentase nilai yang diperoleh dari ahli media sebesar $95 \%$ dan dari ahli materi sebesar 92,5\%. Kedua nilai tersebut termasuk dalam kategori sangat baik, sehingga media dapat digunakan sebagai media pembelajaran. Ketertarikan siswa terhadap media pembelajaran interaktif ini sebesar 94\%, sehingga dapat dikategorikan sangat baik. Persentase tersebut diperoleh dari hasil respons angket siswa. Berdasarkan hasil uji coba yang dilakukan peneliti diperoleh $\mathrm{N}$ gain sebesar 81,64 dan dikategorikan efektif. Hal ini menunjukkan bahwa media pembelajaran menggunakan articulate storyline efektif digunakan sebagai media pembelajaran keterampilan menyimak teks laporan hasil observasi di SMA N 3 Bantul tahun 2021/2022.

Media pembelajaran keterampilan menyimak teks laporan hasil observasi dengan articulate storyline di SMAN 3 Bantul Tahun Ajaran 2021/2022 memiliki keterbatasan yaitu siswa harus mengunduh dahulu sebelum menggunakannya.

Silampari Bisa: Jurnal Penelitian Pendidikan Bahasa Indonesia, Daerah, dan Asing Vol. 4, No. 2, 2021 
Untuk itu, harapan bagi peneliti lanjutan bisa mengembangkan media pembelajaran menyimak dengan hasil siswa tidak harus mengunduh dahulu sebelum menggunakannya.

\section{Daftar Pustaka}

Agustien, R., Umamah, N., \& Sumarno, S. (2018). Pengembangan Media Pembelajaran Video Animasi Dua Dimensi Situs Pekauman di Bondowoso dengan Model ADDIE Mata Pelajaran Sejarah Kelas X IPS. Jurnal Edukasi, 5(1), 19-23. https://doi.org/10.19184/jukasi.v5i1.8010

Ambarawati, N. K. (2020). Peningkatan Hasil Belajar Menulis Teks Laporan Hasil Observasi dengan Pendekatan Integratif. Jurnal Pembelajaran Prospektif, 5(1). doi:10.26418/jpp.v5i1.40638

Nugraheni, T. D. (2018). Pengembangan Media Pembelajaran Interaktif Menggunakan Articulate Storyline pada Mata Pelajaran Sejarah Indonesia Kelas X di SMK Negeri 1 Kebumen. Thesis, Universitas Negeri Semarang. http://lib.unnes.ac.id/id/eprint/32545

Nurhayati, I. (2010). Pengaruh Penggunaan Metode Bercerita terhadap Kemampuan Menyimak Siswa pada Mata Pelajaran Bahasa Indonesia. Jurnal Pendidikan UNIGA, 4(1), 54-59. https://journal.uniga.ac.id/index.php/JP/article/view/36

Prathamie, R. R. (2016). Pengembangan Media Pembelajaran Keterampilan Menyimak pada Materi L'identité Menggunakan Adobe Flash Cs6 Berbasis Mobile Application Bersistem Operasi Android untuk Siswa Kelas X. Skripsi. Universitas Negeri Yogyakarta. https://eprints.uny.ac.id/29866/

Rosita, R., Fadiawati, N., \& Jalmo, T. (2017). Efektivitas E-Book Interaktif Sistem Pencernaan Manusia untuk Menumbuhkembangkan Keterampilan Berpikir Kritis Siswa. Jurnal Bioterdidik: Wahana Ekspresi Ilmiah, 5(2), http://jurnal.fkip.unila.ac.id/index.php/JBT/article/view/11689

Sapitri, D. \& Bentri, A. (2020). Pengembangan Media Pembelajaran Berbasis Aplikasi Articulate Storyline Pada Mata Pelajaran Ekonomi Kelas X SMA. Inovtech: Innovation Technology Education, 2(1), 1-8. http://inovtech.ppj.unp.ac.id/index.php/inovtech/article/view/115

Shalikhah, N. D. (2017). Media Pembelajaran Interaktif Lectora Inspire sebagai Inovasi Pembelajaran. Warta LPM, 20(1), 9-16. doi:10.23917/warta.v19i3.2842

Suardinata, I. K. (2021). Unit Kegiatan Belajar Mandiri Jitu Pembelajaran Daring Bermutu di Masa Pandemi. Strategy: Jurnal Inovasi Strategi Dan Model Pembelajaran, 1(1), 17-23. doi:10.51878/strategi.v1i1.287 
Sugiyono. (2019). Metode Penelitian Kuantitatif, Kualitatif, dan R\&D. Bandung: Alfabeta.

Suherli, dkk. (2017). Bahasa Indonesia SMA/MA/SMK/MAK Kelas X. Jakarta: Kementrian Pendidikan dan Kebudayaan.

Trisnawati, T., Puastuti, D., \& Sholeha, L. (2020). Pemilihan Media Pembelajaran Terbaik Sebagai Sarana Pembelajaran yang Efektif Menggunakan Metode SAW. Jurnal Penelitian Ilmu Pendidikan, 13(1), 72-84. doi:10.21831/jpipfip.v13i1.30474

Ulfah, A. (2017). Pengembangan Multimedia Interaktif untuk Pembelajaran Menulis Teks Cerpen. Jurnal Ilmiah Bahasa dan Sastra, 4(1). doi:10.21067/jibs.v4i1.1946

Wena, M. (2009). Strategi Pembelajaran Inovatif Kontemporer Suatu Tinjauan Konseptual Operational. Jakarta Timur: PT Bumi Akasara.

Yumini, S. \& Rakhmawati, L. (2015). Pengembangan Media Pembelajaran Interaktif Berbasis Articulate Storyline pada Mata Diklat Teknik Elektronika Dasar di SMK Negeri 1 Jetis Mojokerto. Jurnal Pendidikan Teknik Elektro, $4(3), \quad 845-849 . \quad$ https://ejournal.unesa.ac.id/index.php/jurnal-pendidikanteknik-elektro/article/view/12673 